\title{
The Psychological Predicament of Contemporary People-Analyzing the Symbolic Meaning of Cage and God in The Hairy Ape
}

\author{
Guodong Zhao \\ Foreign Languages Department of Inner Mongolian Finance and Economics College, Hohhot, China \\ Email: zhaoliu1116@163.com \\ Xiao Liu \\ Foreign Languages Department of Inner Mongolian Finance and Economics College, Hohhot, China \\ Email: zhaoliu1116@163.com
}

\begin{abstract}
This essay is aimed at revealing the psychological predicament of the contemporary people through analyzing the symbolic meaning of cage and god in The Hairy Ape. In the late 19th century and the beginning of the 20th century, capitalism appeared and then developed rapidly. Science and technology were also developing. All these resulted in contemporary people's identity crisis and bewilderment. The analysis of the symbolic meaning of cage and god may be conducive to readers' further comprehension of Yank's experience in finding self-belonging and freedom.
\end{abstract}

Index Terms - Yank, cage, god, predicament

\section{INTRODUCTION}

The Hairy Ape, which consists of eight scenes, is one of the most interesting and thought-provoking works written by O'Neill Eugene. The theme of The Hairy Ape is the contradiction between individuals and society and the process of finding self belonging. After reading the drama carefully, it is easy to find out that the images of cage and god appear frequently. The image of cage runs through the whole text, in which it lays a gloomy keynote. Both Yank's living place and working place are all like cages which are often used to confine animals. The office where the Industrial Workers of the World (IWW) local NO.57 locates, as well as the prison and the gorilla cage are also images of cage. Yank's psychological process of finding his own identity and self belonging just means jumping from one prison to another.

The image of god in the text is of the same importance as the image of cage. With the development of science, technology and capitalistic economy, people's belief systems have been changed substantially. In addition, with Nietzsche's declaration of "the god died" many people are stuck in bewilderment. They do not know what to do, because in their minds, people can't live without god. As O'Neal says: "the playwrights should explore the root of contemporary drawbacks, i.e., the old god has died, while science and materialism fail to provide a new god to satisfy people's original religious instinct - finding the meaning of life to comfort the fear of death".

Yank, who is very proud and conceited at first, ignores god. At last, however, when he is dying, he calls for god, crying "Christ, where do I get off at? Where do I fit in?" It is only the weak who would admire and need god. Yank is no doubt a weak person. As a representative of contemporary people, we can see his longing for freedom and expectation for self belonging from Yank's changing process in seeking the value of existence.

\section{ANALYSIS OF THE PLAY}

\section{A. Generalizing The Hairy Ape}

Yank was a fireman in a luxury liner. He was broader, fiercer, more truculent, more powerful, and surer of himself than his colleagues. As a result, he was very arrogant and proud, believing that he was the foundation of the world; it was he who created the speed and everything. He also had strong dignity and wanted to be respected by every people. However, his dignity and proud were badly dented by Mildred, who called him a filthy beast when she first saw him. It seemed that he was stuck in bewilderment since then.

He decided to revenge Mildred and the alike. So he went to the Fifth Avenue to insult the rich people. Unfortunately, he was arrested and put into prison after punching a fat gentleman. When he escaped from the prison, he went to the Industrial Workers of the World (IWW) to seek his belonging. Again he was driven away by the organization, considering him as a spy by mistake. This time he lost himself completely.

Earlier, he thought that he controlled the world, but now the world controls him. He wasn't on earth or heaven, he was in the middle, trying to separate them, but suffering all the punches from both. Then he went to the zoo and talks to 
a gorilla. Now he knew for sure that he had no past, no future, only present. He thought he and the gorilla belonged to the same club. So he released it and shook hands with it, but unfortunately, he was squeezed to death.

He was a representative of the primitive society. He blindly admired his own strength and ignored the reality and his class belonging. He had no consciousness of classes, so when he felt insulted by Mildred, he just wanted to revenge her alone, not her class. He was defiant to Long's and Paddy's thoughts. So after his dignity was cracked down, he found himself in a fix, not knowing where to start and where to go.

\section{B. The Symbolic Meaning of Cage}

Yank appears in a luxurious transatlantic liner sailing on the sea. In contrast, his living space is rather narrow.

"It is a cramped space in the bowls of a ship, imprisoned by white steel. The lines of bunks, the uprights supporting them, cross each other like the steel framework of a cage." The firemen in their forecastle are "the bewildered, furious, baffled defiance of a beast in the cage." This is the first description of cage. It not only has the symbolic meaning of prison, but also connects the workers with beasts, which echoes with the cage in which the gorilla stays.

Although the liner is very luxurious, the firemen's working environment is also like a prison, no better than their living place. In the stokehole, "dimly-outlined bulks hang over head, shedding just enough light through the murky air laden with coal dust to pile up masses of shadows everywhere".

Just like what Paddy has described the ship "black smoke from the funnels smudging the sea, smudging the decks-the bloody engines pounding and throbbing and shaking, choking our lungs with coal dust-breaking our backs and hearts in the hell of the stokehole, caged in by steel from a sight of the sky like the bloody apes in the Zoo!" Thus we can see that the firemen are kept in "prison" day by day, suffering the exploitation.

In fact, they care for nothing and have no thoughts, but shouting, cursing, laughing, and singing — "a confused, inchoate uproar swelling into a sort of unity, a meaning - the bewildered, furious, baffled defiance of a beast in a cage." When working in the stokehole, they are "outlined in silhouette in the crouching, inhuman attitudes of chained gorillas". They are just beasts in the cage in the eyes of the upper class. In addition, after Yank's watch has come off duty, he doesn't wash himself, so his fellow workers make joke of him "it will stick to you, it will get under your skin. It makes spots on you-like a leopard". This indicates that dirt is connected with beasts. In this respect, readers can have a more comprehensive understanding of the symbolic meaning of cage.

Yank "feels himself insulted in some unknown fashion in the very heart of his heart" when Mildred calls him "filthy beast". He is in bewilderment, and goes to the Fifth Avenue to revenge her and the alike. He is put into jail after punching a gentleman. "The cells extend back diagonally from right front to left rear. They do not stop, but disappear in the dark background as if they run on into infinity". The environment in the prison gives readers a cramp feeling.

As he is struggling to escape, "he puts his two feet up so that his position is parallel to the floor like a monkey's; he gives a great wrench backwards. The bar bends like a licorice stick under his tremendous strength". We can see that he is also regarded as a beast, which should be kept in a cage.

The symbolic meaning of cage - prison also extends to the local office of Industrial Workers of the World (IWW), which locates "near the waterfront". "Moonlight on the narrow street, buildings massed in black shadow", just like a scaring cage-like prison. At last, Yank slips in a heap on the floor and dies in the cage which the gorilla stays in.

According to Foucault, the dominant class in society needs a political tool to tame and diminish the dissidents and maintain their ruling. The appearance of prison caters to this demand. The first prison (Zuchthaus) in the world was set up in Hamburg, Germany in 1620. Rather detailed regulations were launched in 1622. Since then, prison's functions as tools to maintain social stability had been bringing into full play.

As a result, Yank's struggling is no more than walking from the iron cage in the forecastle to prison then dying in the cage which is used to keep beasts. In Yank's life, prisons are ubiquitous; his fate is merely walking from one prison to another.

\section{The Symbolic Meaning of God}

People in the 20th century have experienced an unprecedented psychological crisis. On one hand, after Nietzsche says "the god has died!" many people feel the lack of accord with reality, for they lose their beliefs and live in loneliness. So gradually they are stuck in psychological predicament. On the other hand, the rapid development of science and technology has promoted industrial and machinery development. People's productive efficiency and life styles have been changed fundamentally. Science and technology have ignored people's desire for sentiment. So after losing beliefs, they become fascinated with science and technology, which they consider can change everything. Thus they become conceit. Yank is a representative of this kind of people. Though he is merely a fireman in a liner, he regards himself as part of the engines. "It's me makes the stokehole hot! It's me makes it roar! Sure, only for me everything stops".

He also says conceitedly: "I am the end! I am the start! I start something and the world moves. I am the thing in coal that makes it burn; I am steam and oil for the engines; I am the thing in noise that makes you hear it; I am smoke and express trains and steamers and factory whistles; I am the thing in gold that makes it money! I am what makes iron into steel! Steel, that stands for the whole thing! And I am steel-steel-steel! I am the muscles in steel, the punch behind it!" In fact, what Yank says are god-like words. According to The Bible, god not only creates everything, but also a supreme governor. The Poem writes that the governor is king. Once he controls universe, the land cannot be moved! In 
addition, Joshua prays to deity:" let the sun stop at Gideon and the moon at Yaya. So the sun stops as expected, and the moon stops moving". What's more, Aristotle considers God who controls stars as the unmoved mover. From the above we can see that the movement of heavenly bodies is controlled by God. As a worker of the lower class, Yank praises himself as the initial power, with god-like energy and authority. It is no more than a reflection of conceit.

But Yank's pride and conceit are seriously destroyed by Mildred. When "he whirls defensively with a snarling, murderous growl, crouching to spring, his lips drawn back over his teeth, his small eyes gleaming ferociously", Mildred "looks at his gorilla face, as his eyes bore into hers, she utters a low, choking cry and shrinks away from him, putting both hands up before her eyes to shut out the sight of his face, to protect her own". Then she cried whisperingly: "take me away! Oh, the filthy beast"! This startles Yank to reaction. "his mouth falls open, his eyes grow bewildered". "Rage and bewildered fury rush back on Yank. He feels himself insulted in some unknown fashion in the very heart of his pride". He often sits down in the same attitude of "The Thinker" from scene four. He begins to realize that he is merely a hairy ape in other people's eyes. According to Sartre's existentialism, the more one person thinks, the more clearly he will be conscious of freedom. So Yank starts to hate Mildred, for hatred is a resistance to people's intolerance of my freedom. That is to say, when Mildred exerts her right of freedom, she regards Yank as a thing which enjoys no freedom, so Yank hates her and decides to revenge Mildred to prove his value of existence. However, Yank's revenge has another fundamental reason - he is confined in the forecastle and the stokehole like a hairy ape for many years. He has been deprived of freedom and thought, and the value of existence.

The fact is unacceptable to Yank. So he begins to revenge. But he comes across setbacks here and there. After being thrown out by the IWW, he "storms the closed door, but stops bewildered by the confusion in his brain, pathetically impotent. He sits there, brooding, in as near to the attitude of Rodin's "The Thinker" as he can get in his position". He realizes gradually that freedom is the origin of his pain.

He then says to himself: "three square a day, and cauliflowers in the front yard — equal rights—a woman and kids — a lousy vote- and I am all fixed for Jesus, huh? What does that get you? This thing is in your inside, but it is not your belly. Feeding you faces - sinkers and coffee — that don't touch it. It's way down — at the bottom. You can't grab it, and you can't stop it. It moves, and everything moves. It stops and the whole world stops".

We can see that "it" refers to freedom. Yank understands that freedom is a born right, which can't be chosen and got rid of. So he thinks that he can't go ahead but tries to degenerate.

Yank comes to a gorilla, trying to get comfort from it. Now he thinks they are "both members of the same club-the hairy apes". So he forces the lock on the cage door and throws it open, trying to shake hands with the gorilla. However, he is squeezed to death by its hug. Realizing "got no past to think in, nor nothing that's coming, only what's now-and that don't belong. I am not on earth and I'm not in heaven. I'm in the middle trying to separate them, taking all the worst punches from both of them", he cries with sudden passionate despair:" Christ, where do I get off at? Where do I fit in?" At the end of Yank's life, he entrusts hope to the care of god. According to Nietzsche, only the weak miss and need god's favor and Yank is no doubt the weak.

\section{CONCLUSION}

O'Neal expressed his view of the age in a letter in1929: "the playwrights should explore the root of contemporary drawbacks, i.e. the old god has died, while science and materialism fail to provide a new god to satisfy people's original religious instinct - finding the meaning of life to comfort the fear of death". Nietzsche thinks that if one wants to live a meaningful life, and undertake one's own responsibilities, he or she must abandon god. God must die if one wants to live. Sartre also thinks that it is necessary to discard god if one treats himself or herself seriously. If god exists, one cannot enjoy freedom, and vice versa.

In the late 19th and the early 20th century, "god died" has caused disturbance in belief systems while it brings freedom to people at the same time. Thus the contemporary people are facing an identity crisis. Without the protection of god, people have to find their belonging and value by themselves. As a symbolic of people, however, Yank has failed to find self belonging in the industrialized society. In this age, money and machine have taken the dominant place of people; science and materialism has become the god. Yank is a victim of industrial civilization and machine, he has experienced a changing process from conceit to pain and then to despair, which results from his gradual understanding of his situation. He has tried to change something but failed.

O'Neal says that Yank is a symbolic of everyone who struggles to find self belonging. He is a living person, or he will not be accepted. Yank is you and I as well, he is all persons. So Yank's tragedy becomes the tragedy of people's fighting with themselves. The tragedy has revealed that the dominant class tries hard to suppress people's original power and passion, which long for freedom and self belonging. This kind of suppression can be seen from the symbolic meaning of cage.

Through The Hairy Ape, we can learn that O'Neill's search for self is the efforts made to find self belonging, and the distinct to find the meaning of life. It then resolves social sickness. Though he once said, the characters in his dramas are struggling for the hopeless hope, we can still be shocked by the power, enthusiasm, and sincere emotions expressed in the drama.

\section{REFERENCES}


[1] Guo Jide. (2006). Oneil's Anthology. Beijing: People's Literature Publishing House.

[2] O'Neill Eugene. (1982). The Hairy Ape. Shanghai: Shanghai WenYi Press.

[3] Michel Foucault. (2006). Madness and Civilization. Hohhot: Inner Mongolian People's Publishing House.

[4] Du Xiaozhen. (2007). An Introduction to Sartre. Beijing: The Commercial Press.

[5] Stylan, J .I. (1981). Modern Drama in Theatre and Practice. London: Cambridge University Press.

[6] Du Xiaozhen. (2002). The Burden of Being and Freedom. Jinan: Shan Dong People's Publishing House.

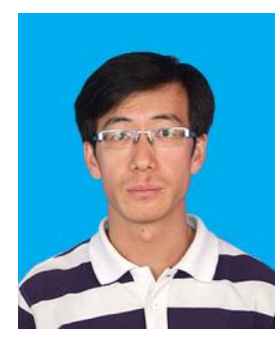

Guodong Zhao was born in Feng Zhen, Inner Mongolia, in 1975. He got his Master's Degree of Art at Foreign Languages College, Inner Mongolia University, Hohhot, Inner Mongolia, P. R. China, in 2008.

$\mathrm{He}$ is currently a lecturer in Foreign Languages Department of Inner Mongolia Finance and Economics College, Hohhot, Inner Mongolia, teaching Linguistics.

His major publications include An Understanding of Pidgin from the Perspective of Chaos Theory at English Language Teaching, published by CCSE, Canada, June, 2010, and Three Models of Equivalence in English Translation of Chinese Classics in the Light of the Theory of Translation as Selection and Adaptation at JLTR, Academy Publisher, Finland, 2011. His current research interest is translation and linguistics.

Xiao Liu was born in Bao Tou, Inner Mongolia, in 1976. She got Master's Degree of Art at Foreign Languages College, Inner Mongolia University, Hohhot, Inner Mongolia, P. R. China, in 2008.

She is working as lecturer in Foreign Languages Department of Inner Mongolia Finance and Economics College, Hohhot, Inner Mongolia, teaching Literature. 